\title{
Pemodelan Kesediaan Masyarakat Beranjak Kepada Pengangkutan Aktif
}

\author{
Muhamad Razuhanafi Mat Yazida ${ }^{\text {* }}$, Muhamad Nazri Borhana, Nik Mohd Iznan Tuan Yaakub ${ }^{\mathrm{b}}$, Sharinatol Akmanida Jamaludin ${ }^{\mathrm{b}}$ \\ aJabatan Kejuruteraan Awam \& Struktur, Fakulti Kejuruteraan \& Alam Bina, 43600 UKM Bangi, Selangor, Malaysia \\ bJabatan Kejuruteraan Awam, Politeknik Ungku Omar, 31400 Ipoh, Perak, Malaysia \\ *Corresponding author: razuhanafi@ukm.edu.my
}

\begin{abstract}
Active transport is vital to ensure urban living in a clean, healthy and quality environment. Today, rapid motorisation in Malaysia has been associated with congestion and accidents. Besides, carbon gas emission is polluted the environment and grossly affect people's quality of life. This study is aimed to predict the variable that effect shift to active transport for short trips. The study employed a survey method, where a set of questionnaire was distributed to 400 samples involved population of five sub-districts in Kota Bharu, which is within $12 \mathrm{~km}$ radius from the city centre. The data indicated that almost $100 \%$ of the respondents and their households use motorised for daily activities. In addition, $52 \%$ of respondents agreed to switch to active transport and $48 \%$ the rest did not agree. Willingness to shift to active transport based on state preference survey is significantly influence by level of education and occupation. A study using logistic regression has shown that the highest level of education and occupation of an increasingly less likely a user is to use active transportation. The findings of this study can help relevant agencies such as transportation planners and urban planners to introduce the use of active transport as a mode of transport in city centre.
\end{abstract}

Keywords: Active transport; logistic regression; motorized; cycling

\begin{abstract}
Abstrak
Pengangkutan aktif adalah penting bagi menjamin kehidupan dalam persekitaran yang bersih, sihat dan berkualiti tinggi. Hari ini, sistem pengangkutan di bandar-bandar Malaysia sering dikaitkan dengan imej buruk seperti kesesakan, kemalangan dan ketidakcekapan pengangkutan awam sebagai alternatif. Selain itu kesan pembebasan gas karbon ke ruang atmosfera menyumbang kepada pencemaran alam dan menjejaskan aspek kualiti kehidupan secara umumnya. Kajian ini bertujuan meramalkan pembolehubah yang mempengaruhi pengguna kenderaan bermotor beranjak kepada mod penggunaan pengangkutan aktif untuk perjalanan jarak dekat. Kajian ini melibatkan pengumpulan data secara kaji selidik ke atas 400 orang responden di lima mukim di sekitar Kota Bharu iaitu dalam jarak perjalanan $12 \mathrm{~km}$ dari pusat bandar. Hasil kajian awal mendapati $100 \%$ responden dan isirumah mereka menggunakan kenderaan bermotor untuk aktiviti harian, manakala 52\% responden bersetuju untuk bertukar kepada kenderaan tidak bermotor dan $48 \%$ tidak bersetuju untuk bertukar. Hasil kajian mendapati faktor yang amat mempengaruhi keinginan menggunakan pengangkutan aktif adalah tahap pendidikan dan jenis pekerjaan. Model regresi logistik menunjukkan semakin tinggi tahap pendidikan dan pekerjaan seseorang semakin kurang kecenderungan pengguna untuk menggunakan pengangkutan aktif. Dapatan kajian ini diharap membantu pihak-pihak terlibat dalam perancangan pengangkutan ke arah merealisasikan penggunaan pengangkutan aktif di bandar-bandar.
\end{abstract}

Kata kunci: Kenderaan bermotor; regresi logistic; pengangkutan aktif ;berbasikal

() 2017 Penerbit UTM Press. All rights reserved

\subsection{PENGENALAN}

Pengangkutan aktif adalah pengangkutan yang diaktifkan dengan mengguna tenaga manusia seperti berjalan, berbasikal, mengguna kerusi roda dan papan luncur. Ia juga lebih dikenali sebagai pengangkutan tidak bermotor ( Mitra \& Buliung, 2012; Pabayo, Maximova, Spence, Vander Ploeg,\& Veugelers, 2012). Pengangkutan aktif dapat menyokong meningkatkan kesihatan dan kecergasan. Ia juga dapat mengurangkan pencemaran dan kemalangan dengan menggantikan perjalanan kenderaan bermotor terutama pada jarak yang dekat. Penggunaan pengangkutan aktif dapat mengurangkan perjalanan dengan kenderaan bermotor yang memberi faedah dari segi ekonomi, sosial dan alam sekitar. Terdapat bukti bahawa ramai orang mahu menggunakan pengangkutan lebih aktif jika diberi sokongan dan galakan yang sesuai (Mitra \& Buliung, 2012; Chillon, Ortega, Ruiz, Veidebaum, Oja, Maestu \& Sjostrom, 2010; Gordon-larsen, Nelson \& Beam, 2005; Huang, Stinchcomb, Pickle, Dill \& Berrigan, 2009). Menurut Litman (2003), pengangkutan aktif boleh menyediakan pelbagai faedah kepada individu, perniagaan dan kerajaan apabila ia digunakan sebagai pengganti bagi perjalanan kenderaan bermotor. Pengangkutan aktif adalah amat bermanfaat untuk kanak-kanak, kerana ia menyokong pembangunan fizikal dan sosial mereka Kirby \& Inchley, 2009). Menurut kajian yang dijalankan oleh Pabayo et al., (2012) terhadap kepentingan pengangkutan aktif kepada kanak-kanak yang pergi dan balik ke sekolah untuk aktiviti fizikal harian antara kanak-kanak yang tinggal di luar bandar dan bandar di Kanada. Pelajar yang tinggal di kawasan bandar adalah lebih cenderung untuk menggunakan pengangkutan aktif disebabkan tempat kediaman mereka purata $0.8 \mathrm{~km}$ dari sekolah manakala sekolah di kalangan kanak-kanak luar bandar berada $18.5 \mathrm{~km}$. Kajian juga mencadangkan mewujudkan persekitaran yang selamat bagi kanak-kanak untuk berjalan kaki ke sekolah . 
Perancang bandar telah mencadangkan bahawa ciri-ciri persekitaran boleh menyokong perjalanan yang aktif (berjalan dan berbasikal) dan mengurangkan tingkah laku yang tidak aktif. Kenyataan ini disokong oleh Freeman et al., (2012) dalam kajian beliau terhadap 8064 responden di New York pada tahun 2003 berdasarkan penglibatan dalam perjalanan aktif di kawasan tersebut. Data telah dianalisis pada penglibatan dalam perjalanan aktif dan kekerapan berjalan atau berbasikal menggunakan regresi binomial negatif. Secara keseluruhan, $44 \%$ daripada responden melaporkan tidak membuat perjalanan aktif disebabkan ciri-ciri persekitaran yang tidak menyokong untuk perjalanan aktif. Aktiviti berbasikal merupakan perjalanan aktif yang popular kepada manusia untuk beberapa dekad yang lalu. Pada hari ini, berbasikal adalah satu cara yang paling baik untuk bergerak dari satu tempat ke satu tempat yang lain dalam jarak yang dekat. Penggunaan basikal dapat menjaga kesihatan, alam sekitar, sosial dan faedah komuniti yang lain. Dengan penggunaan basikal juga, penggunaan gas dan bahan api dapat dikurangkan serta meninggikan kualiti hidup (Chillon,Ortega, Ruiz, Veidebaum, Oja, Maestu \& Sjostrom, 2010; Badland \& Schofield, 2005; Balsas, Rissel, Garrard, Speidel \& Fishman, 2008). Kebimbangan terhadap keselamatan di jalan raya dikenal pasti sebagai penyebab utama untuk tidak berbasikal di negara-negara yang mempunyai kadar berbasikal yang rendah (Bauman, Rissel, Garrard, Ker, Speidel \& Fishman, 2008).

Umur dan jantina individu seseorang sangat mempengaruhi penggunaan kenderaan tidak bermotor. Remaja ( 10-20 tahun), orang tua, dan masyarakat yang berpendapatan rendah adalah lebih cenderung untuk berjalan dan berbasikal. Remaja dan orang berpendapatan rendah juga lebih cenderung berbasikal untuk perjalanannya. Kajian juga mendapati orang lelaki lebih ramai yang berminat untuk menggunakan basikal dan berjalan kaki berbanding dengan orang perempuan (Garrard, Rose, \& Lo, 2008; Saneinejad, Roorda \& Kennedy, 2012; Seedat, Mackenzie \& Mohan, 2006) Sementara kajian Van Cauwenberg et al.(2012) juga mendapati penduduk yang tinggal di bandar lebih menyukai berbasikal dan berjalan untuk kegiatan harian berbanding dengan penduduk di kawasan luar bandar. Kajian juga menunjukkan perasaan tidak selamat untuk berjalan kaki dan berbasikal di kawasan perumahan, rekreasi terutama kepada golongan wanita. Data soal selidik ini telah dilakukan terhadap 48,879 orang dewasa di Flemish dalam tahun 2004-2010 melalui kaedah analisis regresi logistik pelbagai.

\subsection{METODOLOGI}

Kajian ini dijalankan melalui pendekatan secara kuantitatif. Populasi dalam kajian ini ialah penduduk bandar di 5 mukim dengan populasi 206,602 orang penduduk. Pensampelan rawak berkelompok berdasarkan 5 mukim iaitu Kota Bharu, Panji, Kubang Krian, Kota dan Badang. Pengumpulan data melalui soal selidik dilakukan terhadap tiap-tiap unsur dalam semua kelompok yang telah terpilih. Sekaran (1992), menyebut bahawa jika sampel dibahagikan kepada sub-sampel (lelaki/perempuan) maka saiz sampel yang minimum 30 peratus dari setiap kategori akan diperlukan. Walau bagaimanapun penyelidik, tidak menggunakan kadar 30 peratus sebagai penentuan bilangan responden untuk kajian ini. Penentuan saiz sampel di buat berdasarkan jadual yang dibuat oleh Krejcie \& Morgan (1970). Pada saiz populasi (N) 206,602.00 maka saiz sampel (n) ialah 400. Berdasarkan saiz sampel 400, maka bilangan responden mengikut jantina dan umur ditentukan berdasarkan peratusan populasi mukim. Jadual 1 menunjukkan taburan populasi dan sampel. Saiz sampel ini dianggap oleh penyelidik sebagai satu jumlah yang sesuai berdasarkan kepada kenyataan oleh Sekaran (1992) iaitu saiz sampel yang melebihi 30 dan kurang dari 500 adalah sesuai untuk kebanyakan kajian. Bagi mengenal pasti responden yang terlibat, teknik pensampelan rawak berlapis digunakan kerana responden terdiri dari responden jantina lelaki dan perempuan serta mengikut umur. Steinberg (1999) mengkategorikan umur kepada tujuh tahap iaitu awal remaja (12-15 tahun), pertengahan remaja (16-20 tahun), akhir remaja (21-24 tahun), awal dewasa (25-29), pertengahan dewasa (30-34), akhir dewasa (35-40) dan 40 ke atas adalah matang atau tua. Teknik ini dikatakan yang paling efieyen (Sekaran, 1992) kerana ia dapat memberikan lebih banyak maklumat mengikut saiz sampel yang diberi. Mengikut kajian lepas, jarak perjalanan yang berkesan untuk kenderaan tidak bermotor adalah 12 km (Jinyong, Meiping \& Xiaoguang, 2009; Scheiner, 2010). Oleh itu kesemua instrumen telah ditadbir sendiri oleh penyelidik berdasarkan $12 \mathrm{~km}$ jarak dari tiang kilometer sifar di Pejabat Pos Besar Kota Bharu kepada lima mukim tersebut. Agihan soalan selidik ini hanya diberikan kepada responden yang sukarela untuk memberi kerjasama. Aktiviti survei ini dijalankan selama tiga bulan iaitu pada 22 Feb. 2011 hingga 22 Mei 2012.

Jadual 1 Taburan populasi dan sampel

\begin{tabular}{lcccc}
\hline Mukim & $\begin{array}{c}\text { Jumlah Penduduk } \\
2007\end{array}$ & $\begin{array}{c}\text { Responden } \\
(\%)\end{array}$ & $\begin{array}{c}\text { Lelaki } \\
(\%)\end{array}$ & Perempuan \\
\hline Kota Baharu & 33,830 & $65(16)$ & $33(16)$ & $32(16)$ \\
Panji & 72,790 & $141(35)$ & $70(35)$ & $71(36)$ \\
Kubang Kerian & 54,600 & $106(27)$ & $53(26)$ & $53(27)$ \\
Kota & 13,682 & $27(07)$ & $14(07)$ & $13(07)$ \\
Badang & 31,700 & $61(15)$ & $31(15)$ & $30(15)$ \\
\hline Jumlah & 206,602 & $400(100)$ & $201(100)$ & $199(100)$ \\
\hline
\end{tabular}

\subsection{KEPUTUSAN}

Minat orang ramai yang semakin meningkat dengan aktiviti berbasikal menjadi pemangkin kepada industri penjualan basikal. Satu bancian perjualan basikal di lima kedai perjualan basikal di bandar Kota Bharu. Rajah 1 menunjukkan penjualan basikal di lima kedai tersebut pada lima tahun 2007 sehingga 2011, secara puratanya kadar peratusan penjualan tahunan mencatat 20 peratus penjualan basikal. Keputusan ini menunjukkan ada peningkatan terhadap penggunaan berbasikal setiap tahun. 


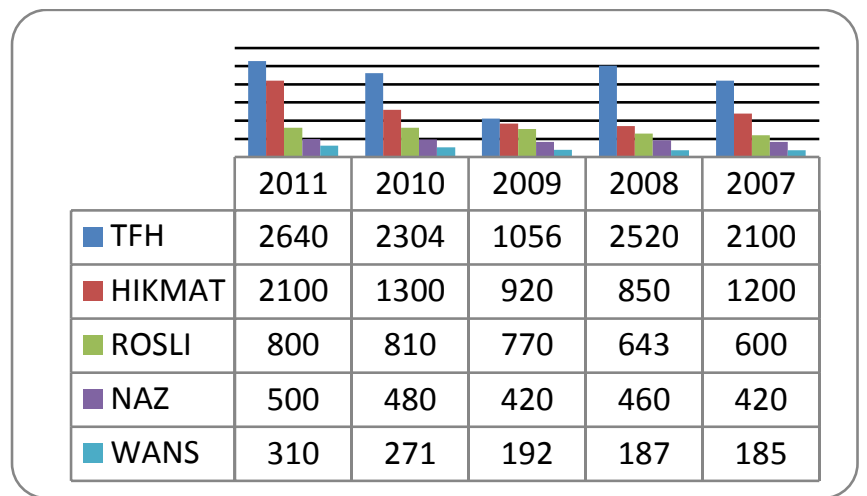

Rajah 1 Bilangan perjualan basikal di lima kedai sekitar bandar Kota Bharu Sumber: Bancian 16-17 Januari 2012.

Rajah 2 menunjukkan carta bar berkenaan faktor yang dipertimbangkan oleh responden dalam membuat pemilihan perjalanan. Hasil kajian mendapati 45 peratus mempertimbangkan faktor jarak perjalanan, 23 peratus responden melihat kepada masa, 21 peratus responden mempertimbangkan kepada kos dan 11 peratus responden mempertimbangkan kepada kemampuan.

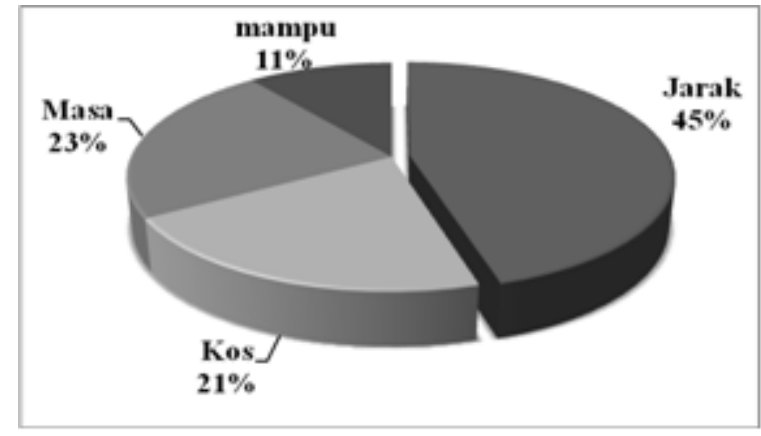

Rajah 2 Faktor pertimbangan perjalanan

Jadual 2 meringkaskan hubungan mod pengangkutan dengan tujuan perjalanan. Perbandingan dilakukan ke atas empat tujuan perjalanan iaitu bekerja, membeli belah, sekolah/institusi dan beriadah/rekreasi. Keputusan menunjukkan penggunaan pengangkutan aktif yang paling tinggi adalah untuk perjalanan ke sekolah atau institusi ( $16 \%$ untuk berbasikal dan $8 \%$ untuk berjalan kaki) manakala perjalanan untuk beriadah atau rekreasi adalah yang kedua tertinggi iaitu 7 peratus untuk berbasikal dan 8 peratus untuk berjalan. Ini menunjukkan mod pengangkutan tidak bermotor adalah lebih sesuai digunakan untuk tujuan perjalanan ke sekolah atau institusi dan beriadah atau rekreasi.

Jadual 2 Agihan mod pengangkutan dengan tujuan perjalanan

\begin{tabular}{lcccc}
\hline \multirow{2}{*}{ Mod } & \multicolumn{4}{c}{ Tujuan Perjalanan } \\
\cline { 2 - 5 } & $\begin{array}{c}\text { Bekerja } \\
(\%)\end{array}$ & $\begin{array}{c}\text { Membeli Belah } \\
(\%)\end{array}$ & $\begin{array}{c}\text { Sekolah/ } \\
\text { Institusi } \\
(\%)\end{array}$ & $\begin{array}{c}\text { Beriadah/ } \\
\text { Rekreasi } \\
(\%)\end{array}$ \\
\hline Memandu & 45 & 39 & 28 & 34 \\
Motosikal & 38 & 37 & 33 & 38 \\
Basikal & 5 & 5 & 16 & 7 \\
Jalan Kaki & 3 & 4 & 8 & 8 \\
Peng. Awam & 9 & 14 & 15 & 13 \\
Jumlah & 100 & 100 & 100 & 100 \\
\hline
\end{tabular}

Rajah 3 menunjukkan peratusan penggunaan basikal oleh isirumah dan responden. Hasil kajian mendapati lebih daripada separuh iaitu 54 peratus (216) tidak mengguna basikal sebagai kenderaan dan hanya 46 peratus (184) yang mengguna basikal. Kajian mendapati majoriti iaitu 100 peratus (400) responden dan isirumah mengguna kenderaan bermotor. Responden juga ditanya keinginan untuk bertukar kepada pengangkutan aktif iaitu berbasikal dan berjalan kaki untuk jarak perjalanan $12 \mathrm{~km}$. Sebanyak 52 peratus responden bersetuju untuk bertukar kepada pengangkutan aktif dan 48 peratus tidak bersetuju untuk bertukar kepada pengangkutan aktif. Ini menunjukkan lebih separuh responden yang mengguna kenderaan bermotor akan berkeinginan kepada pengangkutan aktif. 


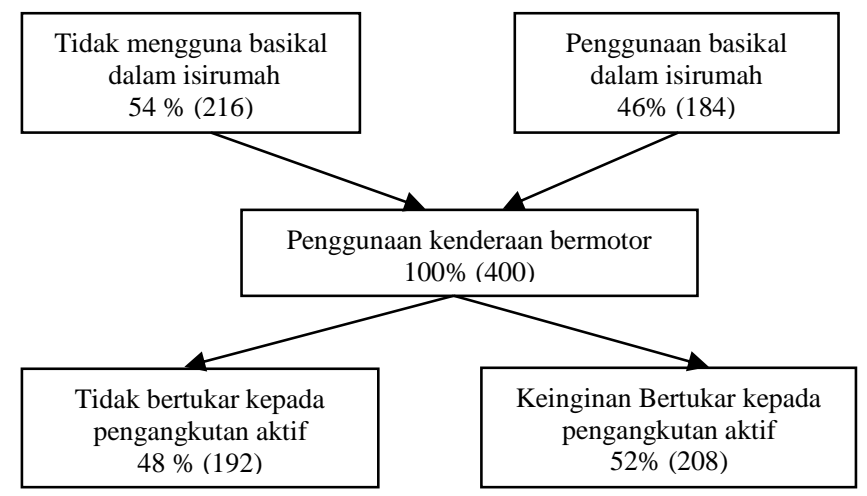

Rajah 3 Analisis kategori perjalanan responden dan isirumah

Jadual 3 menunjukkan kriteria penghuni isirumah yang berkenderaan bermotor, pengangkutan aktif dan jumlah keseluruhan isirumah. Keputusan purata pengangkutan aktif adalah banyak digunakan untuk bilangan penghuni saiz isi rumah yang ramai, bilangan yang masih bersekolah dan bilangan yang tinggal serumah yang tidak bekerja manakala bilangan isirumah yang bekerja dan mempunyai kenderaan lebih cenderung mengguna kenderaan bermotor.

Jadual 3 Kriteria penghuni isirumah terhadap penggunaan kenderaan

\begin{tabular}{lcccccc}
\hline & \multicolumn{2}{c}{ Pengangkutan aktif Isirumah } & \multicolumn{2}{c}{$\begin{array}{c}\text { Kenderaan Bermotor } \\
\text { Isirumah }\end{array}$} & \multicolumn{2}{c}{$\begin{array}{c}\text { Keseluruhan } \\
\text { Isirumah }\end{array}$} \\
\cline { 2 - 7 } & Mean & S.D & Mean & S.D & Mean & S.D \\
\cline { 2 - 7 } & 6.05 & 2.088 & 5.98 & 2.338 & 6.01 & 2.224 \\
Saiz Isirumah & 2.54 & 1.554 & 2.07 & 1.576 & 2.28 & 1.581 \\
Bilangan Bersekolah & 2.04 & 1.616 & 1.75 & 1.952 & 1.88 & 1.809 \\
Bilangan Tidak Bekerja & 1.96 & 1.110 & 2.05 & 1.446 & 2.00 & 1.302 \\
Bilangan Bekerja & 2.46 & 1.125 & 2.74 & 1.325 & 2.61 & 1.243 \\
Bilangan Berkenderaan & & & & &
\end{tabular}

Jadual 4 menunjukkan pengguna pengangkutan aktif secara individu. Pengguna lelaki dan perempuan adalah hampir sama iaitu 51 peratus dan 49 peratus Responden yang berumur bawah 15 tahun iaitu remaja awal sebagai pengguna pengangkutan aktif paling ramai iaitu sebanyak 20 peratus, manakala individu yang sedang belajar paling ramai mengguna pengangkutan aktif iaitu 34 peratus. Sementara itu, 48 peratus responden yang tinggal di kediaman rumah kampung dan 49 peratus responden yang tiada pendapatan yang menggunakan pengangkutan aktif.

Jadual 4 Kriteria pengguna pengangkutan aktif secara individu

\begin{tabular}{|c|c|c|c|}
\hline \multirow[b]{2}{*}{ Kriteria Responden } & \multicolumn{2}{|c|}{ Pengangkutan aktif } & \multirow[b]{2}{*}{ Jumlah (\%) } \\
\hline & Pengguna (\%) & Bukan Pengguna (\%) & \\
\hline \multicolumn{4}{|l|}{ Jantina } \\
\hline Lelaki & 51 & 49 & 49.8 \\
\hline Perempuan & 49 & 51 & 50.3 \\
\hline Jumlah & 100 & 100 & 100 \\
\hline \multicolumn{4}{|l|}{ Umur } \\
\hline 12-15 Remaja Awal & 20 & 12 & 15.5 \\
\hline 16-20 Remaja Pertengahan & 16 & 15 & 15.3 \\
\hline 21-24 Remaja Akhir & 9 & 22 & 15.8 \\
\hline 25-29 Dewasa Awal & 11 & 15 & 13.0 \\
\hline 30-34 Dewasa Pertengahan & 11 & 17 & 14.3 \\
\hline 35-40 Dewasa Akhir & 19 & 9 & 13.8 \\
\hline$>40 \quad$ Matang & 15 & 11 & 12.5 \\
\hline Jumlah & 100 & 100 & 100 \\
\hline \multicolumn{4}{|l|}{ Status Pekerjaan } \\
\hline Tidak Bekerja & 15 & 13 & 14.3 \\
\hline Belajar & 34 & 33 & 33.3 \\
\hline Sendiri & 22 & 17 & 19.5 \\
\hline Kerajaan & 16 & 10 & 12.8 \\
\hline Swasta & 13 & 24 & 19.0 \\
\hline Lain-lain & 0 & 2 & 1.3 \\
\hline Jumlah & 100 & 100 & 100 \\
\hline \multicolumn{4}{|l|}{ Jenis Kediaman } \\
\hline Banglo & 17 & 19 & 18 \\
\hline
\end{tabular}




\begin{tabular}{lccc}
\hline Rumah Berkembar & 5 & 6 & 5.5 \\
Rumah Teres Setingkat & 17 & 14 & 15.8 \\
Rumah teres 2/3 Tingkat & 3 & 5 & 4 \\
Apartment & 0 & 2 & 1 \\
kondomium & 1 & 0 & 0.3 \\
Flat & 2 & 3 & 2.3 \\
Rumah Kedai & 7 & 6 & 6.5 \\
Setinggan & 1 & 3 & 2.0 \\
Rumah kampung & 48 & 42 & 44.8 \\
Jumlah & 100 & 100 & 100 \\
& & & \\
Pendapatan & & & 47.5 \\
Tiada Pendapatan & 49 & 46 & 6.0 \\
$<500$ & 9 & 4 & 18.5 \\
$501-1000$ & 14 & 23 & 18.0 \\
$1001-2000$ & 18 & 18 & 7.0 \\
$2001-3000$ & 8 & 6 & 1.8 \\
$3001-4000$ & 1 & 2 & 1.0 \\
$4001-5000$ & 1 & 1 & 1.3 \\
$>5000$ & 0 & 0 & 100 \\
Jumlah & 100 & 100 & \\
\hline
\end{tabular}

Pengkaji meramalkan bahawa keinginan beranjak kepada berbasikal dan berjalan dalam jarak lingkungan 12 km mungkin disebabkan oleh tujuh faktor variabel peramal iaitu jantina, umur, tahap pendidikan, jenis pekerjaan, pendapatan bulanan, jenis rumah didiami dan isi rumah manakala variabel bersandar adalah keinginan beranjak kepada pengangkutan aktif $(0=$ tidak dan $1=y a)$. Berikut kenyataan hipotesis kajian:

Hipotesis Alternatif, H1: Jantina, umur, tahap pendidikan, jenis pekerjaan, pendapatan bulanan, jenis rumah kediaman dan isi rumah tidak mempengaruhi keinginan beranjak kepada pengangkutan aktif pada jarak lingkungan $12 \mathrm{~km}$.

Hipotesis Nul, $\quad \mathrm{H}_{0}$ : Jantina, umur, tahap pendidikan, jenis pekerjaan, pendapatan bulanan, jenis rumah kediaman dan isi rumah mempengaruhi keinginan beranjak kepada pengangkutan aktif pada jarak lingkungan $12 \mathrm{~km}$.

Dengan menggunakan kaedah Forward Stepwise, model regresi logistik menunjukkan bahawa dua pembolehubah peramal yang meramalkan pembolehubah bersandar keinginan beranjak untuk menggunakan pengangkutan aktif iaitu berbasikal dan berjalan kaki pada jarak kurang daripada $12 \mathrm{~km}$ secara signifikan adalah tahap pendidikan dan jenis pekerjaan. Oleh itu pengkaji menolak hipotesis nul dan melaporkan bahawa secara signifikan $\left(\chi^{2}=37.61, p<.05\right)$, Tahap pendidikan meramalkan sebanyak 12 peratus perubahan dalam pembolehubah bersandar tersebut ( Nilai Nagelkerke $\left.R^{2}=0.120\right)$. Selain itu, secara signifikan $\left(\chi^{2}=55.08, p<.05\right)$, sebanyak 17 peratus perubahan dalam pembolehubah bersandar diramalkan oleh kombinasi variabel peramal tahap pendidikan dan jenis pekerjaan ( variabel peramal jenis pekerjaan menambah sebanyak 5 peratus ramalan).

Graf garisan Rajah 4 jelas menunjukkan bahawa bagi tahap pendidikan, semakin rendah tahap pendidikan seseorang dalam populasi kajian, semakin tinggi keinginannya menggunakan pengangkutan aktif manakala bentuk graf garisan Rajah 5 menunjukkan bahawa frekuensi responden yang tidak mempunyai pekerjaan seperti pelajar dalam populasi kajian, semakin tinggi keinginan mereka untuk beranjak kepada penggunaan pengangkutan aktif.

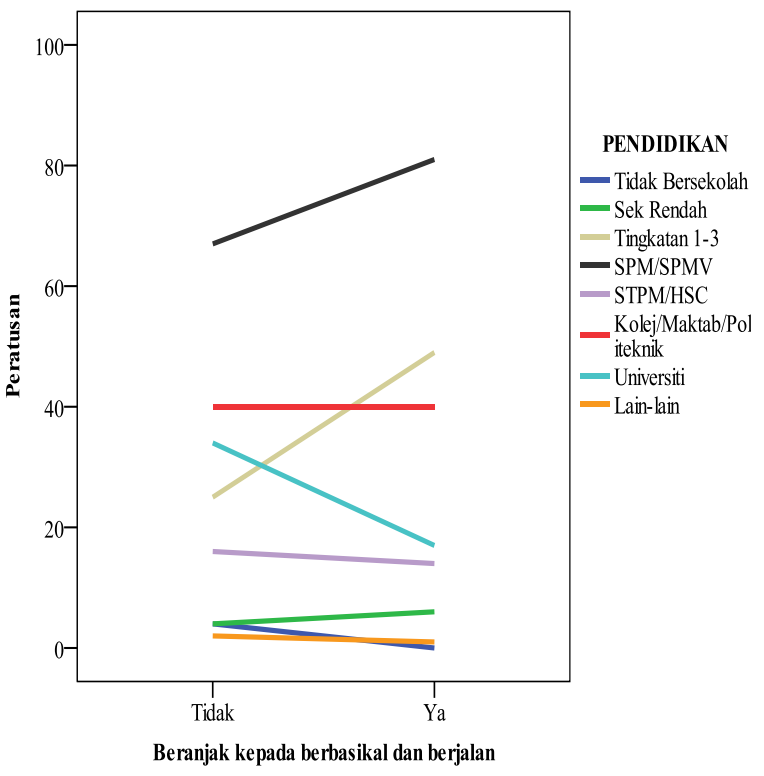

Rajah 4 Graf garisan frekuensi responden beranjak kepada pengangkutan aktif 


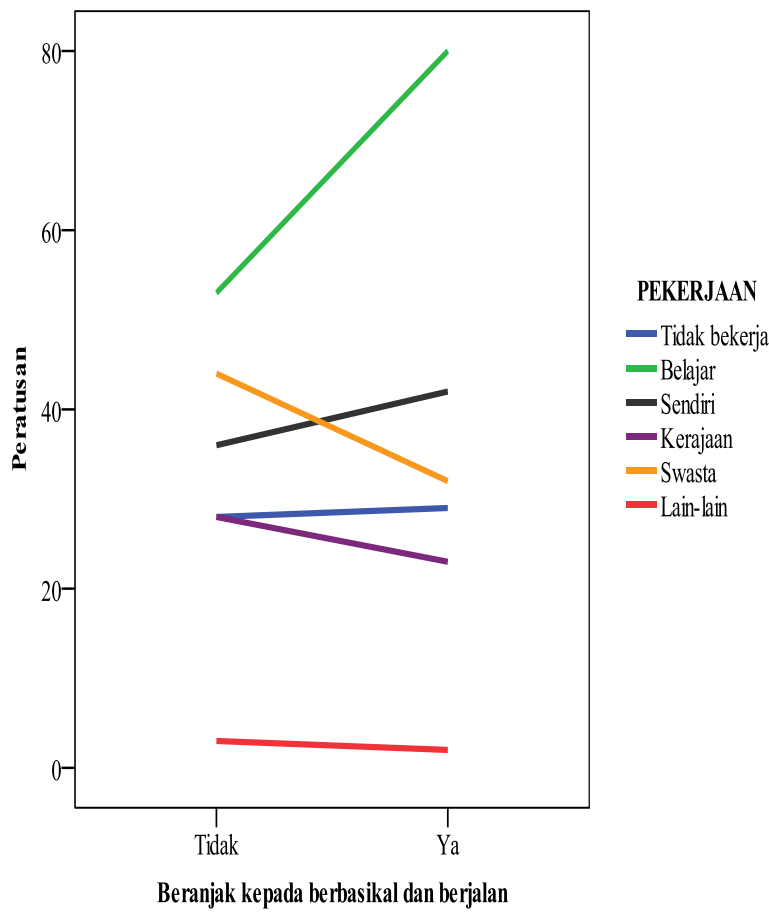

Rajah 5 Graf garisan frekuensi responden beranjak kepada pengangkutan aktif

\subsection{PERBINCANGAN}

Penggunaan pengangkutan aktif merupakan satu kemudahan dan alternatif pengangkutan yang mesra alam, sekali gus membantu menjaga ekosistem dan kualiti alam sekitar serta gaya hidup lebih sihat seperti kajian yang dilakukan ke atas lima bandar raya mesra berbasikal dan berjalan kaki di dunia yang dijadikan model dalam kajian penyelidikan ini iaitu Amsterdam (Belanda), Copenhagen (Denmark), Bogota (Columbia), Barcelona (Sepanyol) dan Berlin (Jerman) (Cervero, Sarmiento, Jacoby, Gomez \& Neiman, 2009; Maibach, Steg \& Anable, 2009; Pucher \& Buehler, 2008; Rojas-Rueda, De Nazelle, Teixido \& Nieuwenhuijsen, 2012).

Daripada hasil kajian yang dijalankan jelas membuktikan keinginan responden beranjak kepada pengangkutan aktif adalah agak menggalakkan dalam jarak perjalanan $12 \mathrm{~km}$ iaitu 52 peratus berbanding hanya 48 peratus yang tidak berkeinginan bertukar kepada kenderaan bermotor sebelum kajian dijalankan. Walaupun penggunaan kenderaan bermotor dalam isirumah 100 peratus tetapi penggunaan basikal dalam isirumah hampir separuh iaitu 46 peratus. Hasil bancian kadar peratusan perjualan tahunan mencatat 20 peratus jualan basikal, keputusan ini menunjukkan ada peningkatan terhadap penggunaan berbasikal setiap tahun. Hasil pemerhatian mendapati kekurangan utama, khususnya di pusat bandar Kota Bharu ialah ketidaksempurnaan sistem pengangkutan aktif. Aktiviti seperti penjajaan tidak berlesen dan peniaga jalanan menghalang laluan pengangkutan aktif, sementara beberapa bangunan tidak memberi akses awam melalui kawasan hartanah mereka. Keadaan ini menyempitkan atau tiada ruang untuk pergerakan pengangkutan aktif. Dalam tahun-tahun kebelakangan ini, terdapat peningkatan beransur-ansur dalam penyediaan elemen-elemen penghubungan pejalan kaki pada bangunan-bangunan baru, tetapi kekurangan masih nyata pada kawasan pembangunan terdahulu. Begitu juga, tidak banyak bangunan menyediakan perlindungan kepada pejalan kaki daripada hujan dan pancaran matahari.

Hasil daripada kajian yang dijalankan sebelum ini (Wardman, Tight \& Page, 2007; Winter, Davidson, Kao \& Teschke, 2011) menunjukkan terdapat beberapa faktor demografi yang mempengaruhi penggunaan pengangkutan aktif seperti bilangan isirumah, jantina, umur, status pekerjaan, jenis kediaman dan pendapatan. Daripada hasil kajian yang dijalankan ini jelas membuktikan penggunaa pengangkutan aktif digunakan oleh bilangan penghuni saiz isi rumah yang besar (purata 6 orang), bilangan yang bersekolah dan bilangan isi rumah yang tidak bekerja manakala isirumah yang bekerja lebih cenderung mengguna kenderaan bermotor. Manakala secara individu kajian mendapati jantina tidak memainkan peranan yang ketara mempengaruhi penggunaan kenderaan tidak bermotor kerana keputusan menunjukkan hampir sama ramai iaitu 51 peratus lelaki dan 49 peratus perempuan dibandingkan dengan kajian lepas (De Vries, HopmanRock, Bakker, Hirasing \& Van Mechelen, 2010; Torquato, Sant \& Bianchi, 2007) lebih digemari oleh lelaki. Faktor demografi yang lain mempengaruhi penggunaan pengangkutan aktif adalah umur iaitu remaja awal yang berumur bawah 15 tahun sebagai pengguna pengangkutan aktif paling ramai iaitu sebanyak 20 peratus, manakala individu yang sedang belajar paling ramai mengguna kenderaan tidak bermotor iaitu 34 peratus. Sementara itu, 48 peratus responden yang tinggal di kediaman rumah kampung dan 49 peratus responden yang tiada pendapatan yang menggunakan pengangkutan aktif.

Hasil analisis regresi logistik menunjukkan bahawa daripada tujuh pembolehubah peramal iaitu jantina, umur, tahap pendidikan, jenis pekerjaan, pendapatan bulanan, jenis rumah kediaman dan isi rumah dalam kajian ini, dua pembolehubah, iaitu tahap pendidikan dan jenis pekerjaan menyumbang kepada perubahan variabel keinginan beranjak kepada penggunaan pengangkutan aktif secara signifikan. Dalam kajian ini, 12 peratus keinginan beranjak kepada pengangkutan aktif dipengaruhi oleh tahap pendidikan dan sekiranya faktor tahap pendidikan dan jenis pekerjaan diambil kira bersama, 17 peratus keinginan beranjak kepada berbasikal dan berjalan tersebut dipengaruhi 
oleh kedua-dua faktor tersebut bersesuaian dengan kajian yang dilakukan oleh Huang et al. (2009); Cervero et al. (2009) dan Hankey et al. (2012).

\subsection{KESIMPULAN}

Dapatan kajian ini membantu pihak-pihak terlibat dalam perancangan pengangkutan ke arah merealisasikan penggunaan pengangkutan aktif di bandar-bandar dengan mengambil faktor-faktor hasil kajian ini seperti mengutamakan kemudahan pengangkutan aktif di kawasan sekolah atau institusi pendidikan dan kawasan rekreasi. Penggalakan penggunaan pengangkutan aktif kepada orang dewasa, individu berpendapatan tinggi dan individu berpendidikan tinggi dengan mengadakan promosi kebaikan penggunaan pengangkutan aktif. Pihak berkuasa pengangkutan juga boleh merumuskan dasar untuk menarik orang ke arah penggunaan mod pengangkutan aktif. Sebagai contoh, model ini menyediakan bukti kukuh untuk menyokong kepentingan kemudahan pengangkutan aktif. Kemudahan-kemudahan ini akan mendorong orang ramai untuk menggunakan mod pengangkutan aktif bukan sahaja untuk rekreasi malah dapat meningkatkan tahap kesihatan.

\section{Penghargaan}

Penulis ingin mengucapkan terima kasih kepada tajaan Kementerian Pengajian Tinggi Malaysia terutamanya Jabatan Pengajian Politeknik (FRGS/1/2014/TK07/JPP/03/1) dan Universiti Kebangsaan Malaysia di atas bantuan kewangan untuk melaksanakan kajian ini.

\section{References}

Badland, H. \& Schofield, G. (2005). Transport, Urban Design, And Physical Activity: An Evidence-Based Update. Transport Research. Part D, D 10(3), 177-196. Balsas, C. J. (2003). Sustainable Transportation Planning On College Campuses. Transport Policy, 10(1), 35-49.

Bauman, A., Rissel, C., Garrard, J., Ker, I., Speidel, R., \& Fishman, E. (2008). Cycling : getting Australia Moving - Barriers, Facilitators And Interventions To Get More Australians Physically Active Through Cycling, 593-601.

Chillón, P., Ortega, F. B., Ruiz, J. R., Veidebaum, T., Oja, L., Mäestu, J., \& Sjöström, M. (2010). Active Commuting To School In Children And Adolescents: An Opportunity To Increase Physical Activity And Fitness. Scandinavian Journal Of Public Health, 38(8), 873-9.

Cervero, R., Sarmiento, O. L., Jacoby, E., Gomez, L. F. \& Neiman, A. (2009). Influences of Built Environments on Walking and Cycling: Lessons from Bogotá. International Journal of Sustainable Transportation, 3, 203-226.

De Vries, S. I., Hopman-Rock, M., Bakker, I., Hirasing, R. a \& Van Mechelen, W. (2010). Built Environmental Correlates Of Walking And Cycling In Dutch Urban Children: Results From The SPACE Study. International Journal Of Environmental Research And Public Health, 7, 2309-24.

FHWA.(1992). Reasons Why Bicycling And Walking Are And Are Not Being Used More Extensively As Travel Modes. FHWA-PD-92.

Freeman, L., Neckerman, K., Schwartz-Soicher, O., Quinn, J., Richards, C., Bader, M. D. M., Lovasi, G. (2012). Neighborhood Walkability and Active Travel (Walking and Cycling) in New York City. Journal Of Urban Health : Bulletin of the New York Academy of Medicine.doi:10.1007/s11524-012-9758-7

Gordon-larsen, P., Nelson, M. C. \& Beam, K. (2005). Diet and Physical Activity Associations among Active Transportation, Physical Activity , and Weight Status in Young Adults. 13(5).

Garrard, J., Rose, G. \& Lo, S. K. (2008). Promoting Transportation Cycling For Women: The Role Of Bicycle Infrastructure. Preventive Medicine, 46(1), 55-9.

Huang, L., Stinchcomb, D. G., Pickle, L. W., Dill, J. \& Berrigan, D. (2009). Identifying Clusters Of Active Transportation Using Spatial Scan Statistics. American Journal Of Preventive Medicine, 37(2), 157-66.

Hankey, S., Lindsey, G., Wang, X., Borah, J., Hoff, K., Utecht, B., \& Xu, Z.(2012). Estimating Use Of Non-Motorized Infrastructure: Models of bicycle and pedestrian traffic in Minneapolis, MN. Landscape and Urban Planning, 107, 307-316.

Jinyong, J., Meiping, Y. \& Xiaoguang, Y. (2009). Statistical Analysis on Non-motorized Transportation Mode Choice Considering Trip Distance and Car Availability. 2009 International Conference on New Trends in Information and Service Science, 181-186.doi:10.1109/NISS.2009.149

Kirby, J. \& Inchley, J. (2009). Active Travel To School: Views Of 10-13 Year Old Schoolchildren in Scotland. Health Education, 109(2), 169-183.

Krejcie, R. V \& Morgan, D. W. (1970). Determining Sample Size for Research Activities. Educational and Psychological Measurement, 30, 607-610.

Litman, T. (2003). Active Transportation Policy Issues. Victoria Transport Policy Institute.

Mitra, R. \& Buliung, R. N. (2012). Built Environment Correlates Of Active School Transportation: Neighborhood And The Modifiable Areal Unit Problem. Journal of Transport Geography, 20(1), 51-61.

Maibach, E., Steg, L. \& Anable, J. (2009). Promoting Physical Activity And Reducing Climate Change: Opportunities To Replace Short Car Trips With Active Transportation. Preventive Medicine, 49, 326-7.

Martens, K. (2004). The Bicycle As A Feedering Mode: Experiences From Three European Countries. Transportation Research Part D: Transport and Environment, 9 , 281-294.

Pabayo, R., Maximova, K., Spence, J. C., Vander Ploeg, K., Wu, B., \& Veugelers, P. J. (2012). The Importance Of Active Transportation To And From School For Daily Physical Activity Among Children. Preventive Medicine, 55(3), 196-200.

Pucher, J. \& Buehler, R. (2008). Making Cycling Irresistible: Lessons from The Netherlands, Denmark and Germany. Transport Reviews, 28, 495-528.

Rojas-Rueda, D., De Nazelle, a, Teixidó, O. \& Nieuwenhuijsen, M. J. (2012). Replacing Car Trips By Increasing Bike And Public Transport In The Greater Barcelona Metropolitan Area: A Health Impact Assessment Study. Environment International, 49, 100-9.

Saneinejad, S., Roorda, M. J. \& Kennedy, C. (2012). Modelling The Impact Of Weather Conditions On Active Transportation Travel Behaviour. Transportation Research Part D: Transport and Environment, 17(2), 129-137.

Seedat, M., Mackenzie, S. \& Mohan, D. (2006). The Phenomenology Of Being A Female Pedestrian In An African And An Asian City : A Qualitative Investigation. 139153.

Sekaran, U. (1992). Research Methods for Business: A Skill Building Approach. (New York: John Wiley \& Sons, Inc.

Steinberg, L. D. (1999). Adolescence. 519 (McGraw-Hill College: the University of Michigan.

Scheiner, J. (2010). Interrelations Between Travel Mode Choice And Trip Distance: Trends in Germany 1976-2002. Journal of Transport Geography, 18 , 75-84.

Torquato, R. J., Sant, A. \& Bianchi, A. (2007). Pedestrians’ Behaviours : Errors, Violations And Lapses, 1-6.

Van Cauwenberg, J., Clarys, P., De Bourdeaudhuij, I., Van Holle, V., Verté, D., De Witte, N., De Donder, L. (2012). Physical Environmental Factors Related To Walking And Cycling In Older Adults: The Belgian Aging Studies. BMC Public Health, 142.

Wardman, M., Tight, M. \& Page, M. (2007). Factors Influencing The Propensity To Cycle To Work. Transportation Research Part A: Policy and Practice, 41, 339350.

Winters, M., Davidson, G., Kao, D. \& Teschke, K. (2011). Motivators And Deterrents Of Bicycling: Comparing Influences On Decisions To Ride, 153168.doi:10.1007/s11116-010-9284. 